\title{
Morphology, Histology and Histochemistry of the Digestive System of South American Catfish (Rhamdia quelen)
}

\author{
Morfología, Histología e Histoquímica del Tubo Digestivo del Bagre Sudamericano (Rhamdia quelen)
}

"Hernández, D. R.; **'Pérez Gianeselli, M. \& **** Domitrovic, H. A.

HERNÁNDEZ, D. R.; PÉREZ GIANESELLI, M. \& DOMITROVIC, H. A. Morphology, histology and histochemistry of the digestive system of South American catfish (Rhamdia quelen). Int. J. Morphol., 27(1):105-111, 2009.

SUMMARY: The purpose of the present work was the anatomical, histological and histochemical description of Rhamdia quelen juvenile digestive system. Samples of gut were fixed, dehydrated and included in paraffin and then stained with haematoxylin and eosin. For the identification and differentiation of mucosubstances the preparations were treated with Periodic Acid Schiff, Alcian Blue pH 0,4 and 2,5 and PAS/AB pH 2,5. Anatomical details of the oesophagus were like a short tube with primary and secondary mucous folds. The stratified epithelium is composed of three cellular types: small cells, abundant goblet cells with acid and neutral mucosubstances (MS) and large acid cells. The stomach is J-shaped and its mucosa presents broad and deep folds in relaxing state. Histologically, the stomach shows three different regions: cardiac, fundic and pyloric region. The luminal surface of the epithelium consists of a layer of secretory columnar cells of neutral MS. Tubuloacinar glands were surrounded by connective and muscular smooth fibers bundle. The intestine extends from the stomach until the anus, and four different sections can be distinguished: ascending, descending, convoluta and terminal straight. It was identified a simple columnar epithelium mainly composed by two cellular types: absorptive cell and goblet cell neutral MS secretory. On the basis of the anatomical and histological study carried out, we conclude that $R$. quelen presents an alimentary canal compatible with species that possess omnivorous nutritious habits.

KEY WORDS: Rhamdia quelen; Histology; Digestive System.

\section{INTRODUCTION}

The anatomical and histological structure of the digestive system was described in several autochthonous teleosts fish from South America for different authors (Pignalberi et al., 1973; Domitrovic, 1992a-b; Seixa Filho et al., 2001; Flores Quintana \& Portella, 2003a-b). Almost all emphasize the importance of the knowledge of these features, which reveal many particularities dependent on the diversity of the nourishing rate and manners of life of every species, especially. The fish, in general, needs the same nutritious than other terrestrial animals for its growing, reproduction and other vital functions. The knowledge of the food preferences and the variations of the structure of the digestive system of species are useful for the nutritional development researches, preparation of diets and the handling of the feeding (Rotta, 2003). The interest to approach the histological study of these structures resides in the application of the knowledge more about pathology of fishes, as contribution to the development of the fish farming and a rational use of the natural resources (Pereyra et al., 1999).

In this sense, Rhamdia quelen is a native species with good potential of cultivation in fish farming (Rossi \& Luchini, 2005), considered omnivorous (Baldisserotto \& Radünz, 2004) with clear preference to fish, crustaceans, insects, remains of vegetables and organic detritus. The aim of the present study was the description, through optic and scanning electron microscopy (SEM), of the morphology and histology of the digestive system of the South American catfish (R. quelen).

* Instituto de Ictiología del Nordeste, Facultad de Ciencias Veterinarias, Universidad Nacional del Nordeste, (UNNE), Corrientes (Argentina). Scholarship, Consejo Nacional de Investigaciones Científicas y Técnicas (CONICET). E-mail: dhernandez@vet.unne.edu.ar

** Instituto de Ictiología del Nordeste, Facultad de Ciencias Veterinarias, Universidad Nacional del Nordeste, (UNNE), Corrientes (Argentina).

**** Instituto de Ictiología del Nordeste, Facultad de Ciencias Veterinarias, Universidad Nacional del Nordeste, (UNNE), Corrientes (Argentina). Researcher, Consejo Nacional de Investigaciones Científicas y Técnicas (CONICET).

This study was funded by PICT 13.332 and by SGCyT (UNNE) PI 001/2007. 


\section{MATERIAL AND METHOD}

Ten fingerlings of different sex and size of Rhamdia quelen, obtained from natural environments were submitted to fasting for two days for anatomical studies of the digestive system. The specimens were fixed in formaldehyde $5 \%$ after dissection along the ventral side of the abdomen. The characterizations were realized following descriptive aspects: disposition of every segment of the gastrointestinal tract inside the abdominal cavity, and orientation and anastomosis of the mucous folds in each segment. Samples of the different regions of the digestive system were fixed in Bouin solution for 18 hours, and then were dehydrated and included in paraffin. Sections (1-3 $\mu \mathrm{m}$ thickness) were stained with haematoxylin and Eosin (H\&E) and histochemical techniques for the identification and differentiation of mucosubstances with periodic acid schiff (PAS), Alcian Blue (AB) $\mathrm{pH} \mathrm{0,4} \mathrm{and} \mathrm{2,5} \mathrm{and} \mathrm{PAS/AB} \mathrm{pH}$ 2,5. The segments for SEM were dehydrated by critical point and sputtered with gold - palladium. The samples were mounted and observed in a JEOL5800LV SEM, belonging to the Electronic Microscopy Service of the Secretary of Science and Technology (UNNE).

\section{RESULTS}

Anatomy. The oesophagus is a short and muscular tube that communicates the pharyngeal cavity with the stomach. In the oesophageal mucosa were observed primary, secondary mucosal folds and some like thirds folds with longitudinal dispositions. These appears since the pharyngeal region being more abundant in the posterior portion, which allow a good distention for the step of the food (Fig. 1, A).

The J-shaped stomach localized behind of the liver, is a muscular sack placed between the oesophagus and the intestine, and has broad and deep folds in rest state (Fig. 1, D). Micro-anatomical features of the luminal surface of the organ were evidenced by SEM observations, showing gastric areas delimited by pits in which there the gastric glands end (Figs. 2 and 3).

The intestine is the longest part of the digestive tube. It spreads from the pyloric region of the stomach until to the anus and present an approximately uniform diameter in all its length, with a gradual decrease towards the terminal portion. Initially its orientation is in postero-anterior direction up to first curvature where acquires an anteroposterior direction. The last portion spreads up to the second

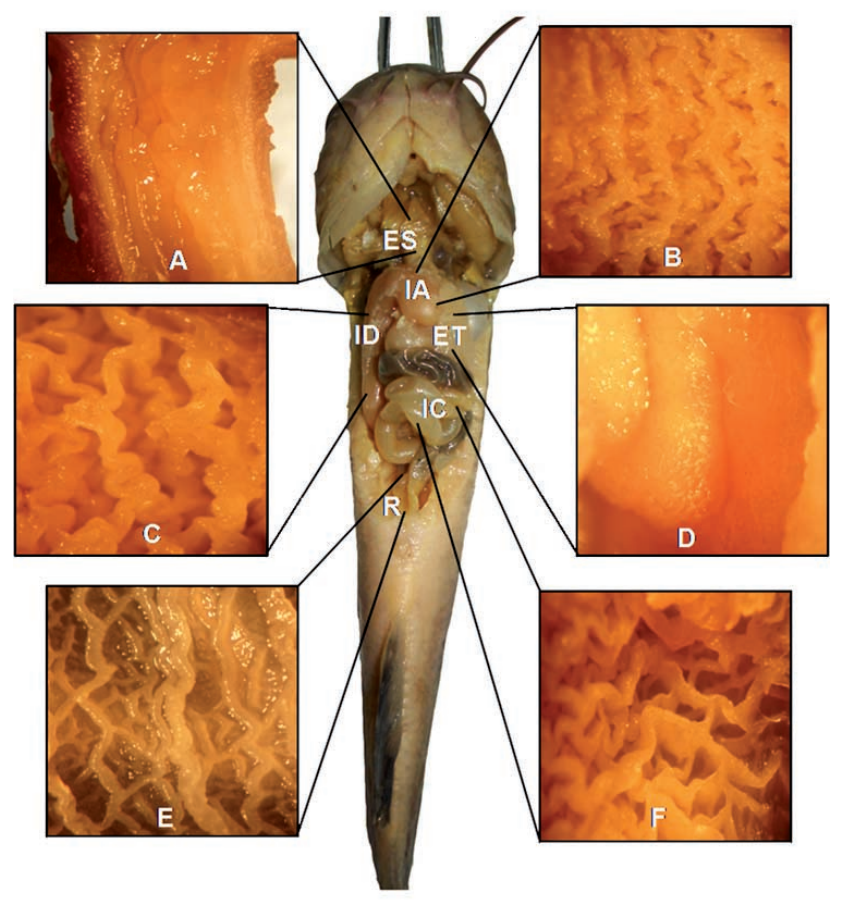

Fig. 1. Digestive system of Rhamdia quelen. Specimen dissected ventrally to show the nature and disposition of the alimentary tract (1). Different regions of the alimentary tract longitudinally sectioned to show nature of the mucosal folds (A to F). Oesophagus (ES); stomach (ET); ascending intestine (IA); descending intestine (ID); convolute intestine (IC); straight terminal portion (R).

curvature, where it is continued with a series of circumvolutions, and after a short distance it comes back to an antero-posterior straight direction that ends in the anus. Hereby, the intestine can be divided in four portions: ascending, descending, convoluta and straight terminus. The first one goes from the pylorus up to the first curvature, the second one from this one up to the second curvature, the third one belongs to the circumvolutions, and the fourth one from these until to the anus.

In the ascending segment were observed numerous mucous longitudinal folds in a zig-zag pattern, with different heights (primary and secondary) (Fig. 1, B). In the descending portion, folds were branched out, also of different height (Fig. 1, C), whereas in the convoluta portion they were abundant, thin and zig-zag oriented (Fig. 1, F), adopting a longitudinal disposition in the last portion where they became thicker and less numerous (Fig. 1, E).

Histology. Histologically, the digestive system of R. quelen was similar to other vertebrates, constituted by four layers: mucosa, submucosa, muscularis and serosa. 
The histochemical staining properties of MS present in the epithelium of the digestive tract are summarized in Table I.

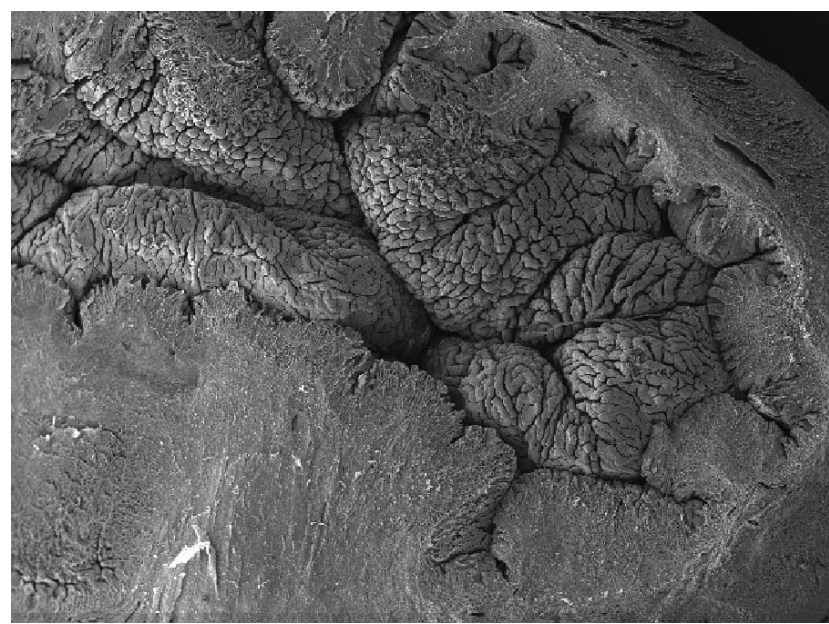

Fig. 2. SEM photography of stomach showing the mucosal surface. $\mathrm{x} 22$.

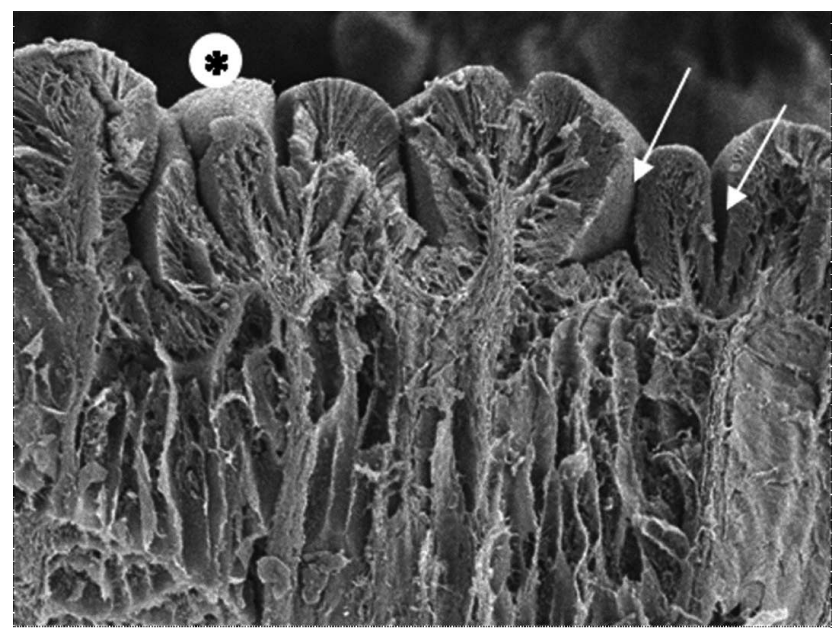

Fig. 3. SEM photography of a cross-section of stomach showing pits (arrows) sorrounding gastric areas (*). x270.

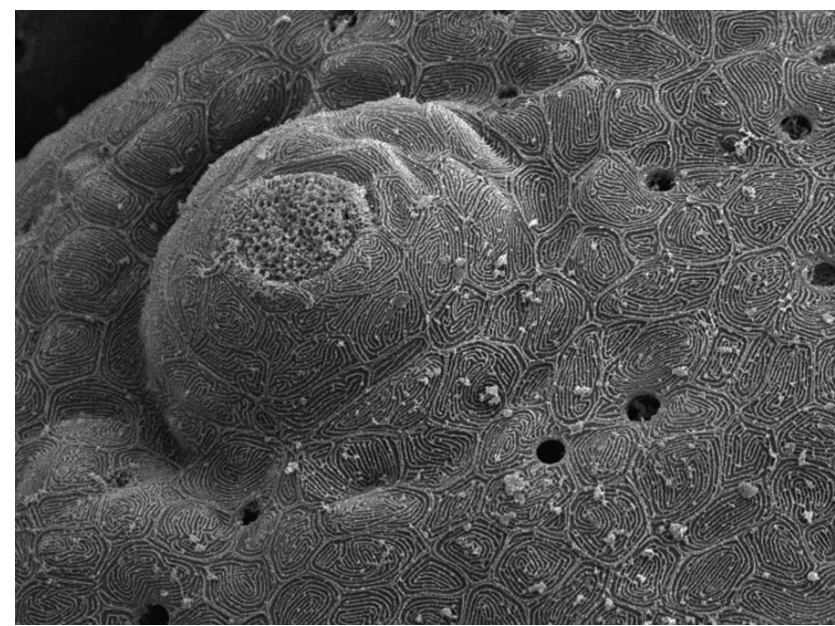

Fig. 4. Rhamdia quelen; SEM micrograph showing a taste bud in the epithelial surface of the proximal oesophagus. x1600.

The mucosa of the oesophagus is covered by a stratified epithelium which became columnar simple towards the stomach. Basically, it is constituted by three cellular types: small cells, abundant goblet cells and large acidophil cells. The small cells were found at different levels of the epithelium, when they come closer the surfaces acquire squamous aspect and rounded nucleus. The goblet cells of the third proximal contained a neutral and acid MS mix. A sequence of procedures using Alcian Blue (AB) at different $\mathrm{pH}$ showed the presence of sulphated MS $(\mathrm{pH} 0,4)$ and $\mathrm{MS}$ with carboxyl groups ( $\mathrm{pH} 2,5)$, whereas towards the third distal they were columnar in shape and weakly PAS positive (Figs. 5, A-B). The large acidophil cells with homogeneous cytoplasm are more abundant in the first portion of the organ and are placed in the middle part of the epithelium. SEM (high magnification) observations showed that in the proximal region of the oesophagus taste buds were distinguished between the epithelial cells (Fig. 4). Submucosa is composed by conjunctive fibers of dense type with abundant collagenous fibers and mainly vascularization. Small muscular fibers sheafs were intermingled in the

Table I. Histochemical reaction of mucosubstances in different portions of the digestive tract of South American catfish (Rhamdia quelen).

\begin{tabular}{|c|c|c|c|c|c|c|c|}
\hline \multirow[b]{2}{*}{ Procedures } & \multicolumn{2}{|c|}{ Oesofagus } & \multirow{2}{*}{ Stomach } & \multicolumn{4}{|c|}{ Intestine } \\
\hline & Proximal & Distal & & AI & DI & CI & $\mathrm{R}$ \\
\hline $\mathrm{AB}$ pH 0,4 & \pm & - & - & - & - & - & - \\
\hline $\mathrm{AB} \mathrm{pH} 2,5$ & ++ & - & - & ++ & +++ & +++ & +++ \\
\hline PAS & + & + & +++ & ++ & ++ & ++ & ++ \\
\hline PAS/AB pH 2,5 (AB dominant) & ++ & - & - & ++ & +++ & +++ & +++ \\
\hline
\end{tabular}

$\mathrm{AB}$, Alcian blue; PAS, periodic acid/Schiff; AI, ascending intestine; DI, descending intestine; CI, convolute intestine; R, Straight terminal portion. Intensity: (-), no staining observed; $( \pm)$, poorly stained; (+), low; $(++)$, medium; (+++), high. 

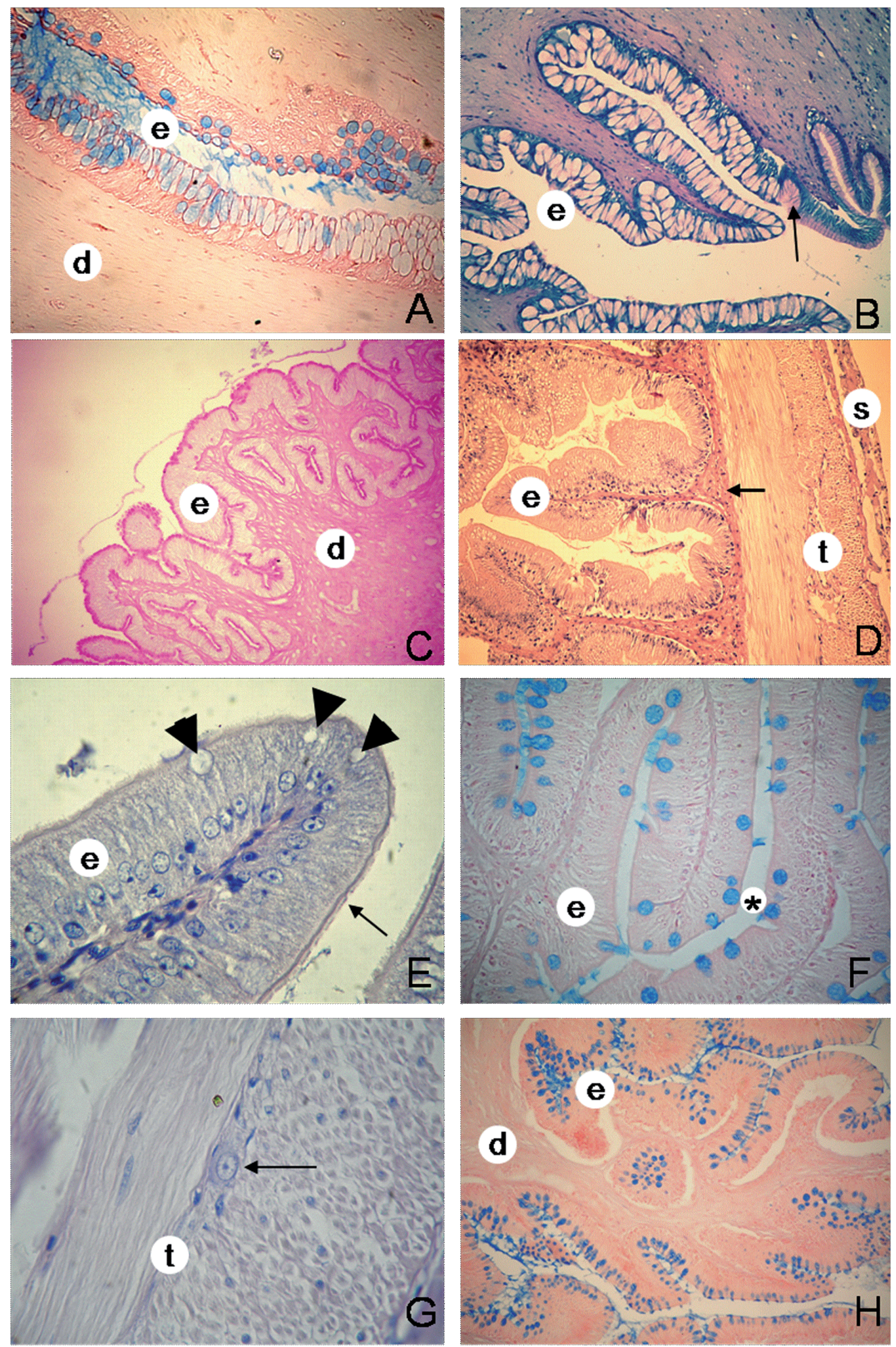
Fig. 5. (A) Oesofagus, proximal third $(\mathrm{AB} \mathrm{pH} 2,5)$ epithelium with stained goblet cells (e); dense connective tissue (d). x20. (B) Oesofagus, distal third. Epithelium withgoblet cells weakly PAS positive (e); arrow showing the transition with stomach. x20. (C) Stomach (PAS). Epithelium mucous secretor (e); dense connective tissue (d). x20. (D) Ascending intestine (H\&E). Epithelium with goblet cells (e); tunica muscularis (t); serosa (s); arrow showing lamina propia-submucosa. x20. (E) Ascending intestine (H\&E). Epithelium (e) with goblet cells (arrow-head); arrow showing microvilli. $x$ 40. (F) Ascending intestine. Epithelium (e) showing stained goblet cells with $\mathrm{AB}$ pH 2,5 (*). x40. (G) Ascending intestine (H\&E) showing neuronal bodies corresponding to the Auerbach mienteric plexus (arrow) in the tunica muscularis (t). x40. (H) Straight terminal portion (PAS/AB pH 2,5) epithelium with staining goblet cells (e); dense connective tissue (d). x40.

conjunctive tissue. The tunica muscularis consisted of the inner longitudinal layer and the outer circular layer of striated muscle. The gross oesofagicus adventitia layer, with areolar connective tissue and abundant blood vessels, was well developed.

The stomach presented three histologically differentiated regions: cardial (non glandular) in relation with the oesophagus, fundus (glandular) the most developed and mainly portion for the digestion activity, and pyloric region, less developed than the others regions. The lining epithelium is constituted by columnar simple epithelium secretor type, with nucleus in basal position and PAS- positive in the apical portion of the cytoplasm. The lamina propia is composed by a thin connective tissue with spread lymphocytes and abundant smooth muscle fibers that accompanies the line folds. The tubuloacinar glands were surrounded with sheaf of smooth muscle fibers, its ducts are opened in the crypts of the mucous folds. In some sectors were observed thin muscularis mucousae or with discontinuous aspects. The submucosa is a thin layer having a very vascularizated, dense connective tissue. The tunica muscularis is constituted by three layers arranged in inner longitudinal, oblique half and outer circular of smooth muscle. The serosa is composed by areolar connective tissue and mesothelium, with abundant blood vessels.

The mucosa of the intestine is covered by simple columnar epithelium with two cellular types: 1) absorptive cells, which are simple columnar cells with an oval nucleus and microvillis in the free border, this cellular type is less numerous in the distal portions and be far diminishing in size, as well as the microvilli (Figs. 5E, and 2) goblet cells, who are arranged among the enterocites, increasing in numer towards the final portion of the intestine. These cells secrete neutral glycoproteins and acid carboxyled sustances, although a weak coloration can be distinguished because of the strongly sulphated MS, as a constant in all long intestine (Figs. $5 \mathrm{~F}$ and $\mathrm{H}$ ). Undifferentiated cells were also observed in the basal portion, and small linfocites close to the epithelium base, identified by its intensely colored nuclei, that would migrate from the base up to the apical epithelium surface. The lamina propia-submucosa, formed by dense vascularizated connective tissue, present linfocites dispersed in the base of the villi, which correspond to associated linfocites to mucosa (Fernandez et al., 2002). The lamina propia spreads up to the part distal of the villi, forming the axis of this structure. The tunica muscularis of the intestine, consisted of the wide inner circular layer, and the outer longitudinal; between both layers can be observed neuronal bodies belonging to the Auerbach mienteric plexus (Figure $5 \mathrm{G})$. The tunica serosa is formed by mesothelium with a vascularizated connective subserous tissue (Fig. 5D).

\section{DISCUSSION}

The morphologic disposition of the digestive system of $R$. quelen is similar to these found in other species (Sis et al., 1979; Pignalberi et al.; Seixa Filho et al.), compatible to that of carnivorous fish, for their rectilinear disposition (Rotta). However, the convolute segment can be considered as an adaptation to an omnivorous diet with carnivorous tendency compatible to that of carnivorous fish (Seixa Filho et al.).

Several authors report the presence of taste buds in the oesophagus mucosa (Diaz et al., 2006; Pignalberi et al.; Sis et al.), added to the striated muscle fibers of the tunica muscularis. It would indicate that the food might be ejected or that the food kept in this segment of the digestive system, which would induce the gastric secretion (Barrington, 1957).

The mucous intestinal (primary and secondary) folds with a zig-zag pattern in the first portions would be suitable adjustments that could retard the speed of the intestinal traffic assuring an ideal absorption. The same ones on having diminished towards the posterior portion and more rectal being done, they would allow the advance of the fecal skittle, similar to the observed in Ambassis spp. (Moitra \& Ray, 1979).

The oesophagus of $R$. quelen shows a mucosubstances mixture: acid and neutral in the first portion and mainly neutral in end portion. This distribution is in agreement with species of carnivorous fish habits described by other authors (Sis et al.; Petrinec et al., 2005). Grau et al. (1992) suggest that mucus secretor cells form a superficial protective layer against infectious and mechanical aggressions, being related also to ions absorption. Likewise, the neutral MS would take part in the food enzymatic digestion and to the absorption processes (Domeneghini et al., 1998). 
The gastric mucosa of the South American catfish possesses a simple columnar epithelium and simple alveolartubule glands surrounded by connective tissue. The apical portion of the epithelium show positive PAS cells. Grau et $a l$. reported that the secretion of neutral mucosubstances for stomach epithelium might be related to the absorption of easily digestible molecules. On the other hand, the mucosubstances facilitate the movement of great size particles of food, as well as protecting the mucosa against the mechanical damages (Petrinec et al.).

Histologically, the intestine was similar to described for other fish teleosts. The absorptive cells decrease in size and number towards the rectum, whereas the goblet cells, with neutral MS, increase. The increase of goblet cells towards posterior would be related to the assimilation of ions and fluids as the mentioned by Petrinec et al. Also Khanna \& Mehrotra (1971) suggest that the goblet cells in this one portion would facilitate defecation.

In many fish, the submucosa presents an estratum compactum or a dense fibro-elástic layer in opposition of the muscularis mucosae. It can be also found Brünner's glands in the submucosa and granular cells. These structures were not observed in the present study on Rhamdia quelen, which agree with previous studies realized by Sis et al. in Ictalurus punctatus and Pignalberi et al. in Pimelodus albicans.

\section{CONCLUSIONS}

Rhamdia quelen presents a digestive tube compatible with a varying diet type, belonging to feeding omnivorous habits, with a well-known trend to ichthyofagia, which would depend on the environments and the food availability. From the fish farming point of view, this species might be fed with balanced dry diets with high place contained of proteins of vegetable origin. The present study contributes bases orientated to future studies in nutrition or adjustments in the current systems of artificial nourishment.

HERNÁNDEZ, D. R.; PÉREZ GIANESELLI, M. \& DOMITROVIC, H. A.Morfología, histología e histoquímica del tubo digestivo del bagre sudamericano (Rhamdia quelen). Int. J. Morphol., 27(1):105-111, 2009.

RESUMEN: El propósito del presente trabajo fue realizar las descripciones anatómica, histológica e histoquímica del sistema digestivo de Rhamdia quelen jóvenes. Las muestras de intestino fueron fijadas, deshidratadas e incluidas en parafina y posteriormente teñidas con hematoxilina y eosina. Para la identificación y diferenciación de mucosubstancias los preparados fueron tratados con ácido periódico de Schiff, Azul Alcian pH 0,4 y 2,5 y PAS/AB pH 2,5. Los detalles anatómicos del esófago mostraron un pequeño tubo con pliegues mucosos primarios y secundarios. El epitelio estratificado presentaba tres tipos celulares: células pequeñas, abundantes células caliciformes con mucosubstancia (MS) ácida y neutra y células grandes ácidas. El estómago tenía forma de J y su mucosa presenta pliegues amplios y profundos en estado de relajación. Histológicamente, el estómago mostraba tres diferentes regiones: cardiaca, fúndica y pilórica. La superficie luminal del epitelio constaba de una capa de células columnares secretoras de MS neutro. Glándulas tubuloacinares estaban rodeadas por tejido conjuntivo y fibras musculares lisas. El intestino se extendía desde el estómago hasta el ano, y cuatro diferentes secciones era posible distinguir: ascendente, descendente, convoluta y terminal recta. Se identificó un epitelio columnar simple, compuesto principalmente por dos tipos celulares: células de absorción y células caliciformes secretoras de MS neutra. Sobre la base de los estudios anatómico e histológico realizados, se concluye que $R$. quelen presenta un canal alimentario compatible con las especies que poseen hábitos nutritivos omnívoros.

PALABRAS CLAVE: Rhamdia quelen; Histología; Sistema digestivo.

\section{REFERENCES}

Baldisserotto B. \& Radünz Neto, J. Criação de jundiá. Santa Maria. Ed. UFSM. 2004, 232 p.

Barrington, E. J. W. The alimentary canal and digestion. In: The Physiology of Fishes. (M. E. Brown, ed.). New York: Academic Press. 1957. pp. 1, 109-161.

Diaz, A. O.; Escalante, A. H.; García, A. M. \& Goldemberg, A. L. Histology and histochemistry of the pharyngeal cavity and oesophagus of the Silverside Odontesthes bonariensis (Cuvier and Valenciennes). Anat. Histol. Embryol.,: 35, 42-6, 2006.

Domeneghini, C.; Straini Pannelli, R. \& Veggetti, A. Gut glycoconjugates in Sparus aurata L. (Pisces, Teleostei). A comparative histochemical study in larval and adult ages. Histol. Histopathol., 13:359-72, 1998.

Domitrovic, H. A. Histochemical study of the digestive tract of Prochilodus platensis (Holmberg, 1880; Pisces, 
HERNÁNDEZ, D. R.; PÉREZ GIANESELLI, M. \& DOMITROVIC, H. A. Morphology, histology and histochemistry of the digestive system of South American catfish (Rhamdia quelen). Int. J. Morphol., 27(1):105-111, 2009.

Prochilodontidae). Revista de Ictiología, 1:35-44, 1992a.

Domitrovic, H. A. Localización histoquímica de fosfatasas alcalina y ácida en el tracto digestivo de Prochilodus platensis (Holmberg, 1880). Revista de Ictiología, 1:6977, $1992 \mathrm{~b}$.

Fernández, A. B.; de Blas, I. \& Ruiz, I. El sistema inmune de los teleósteos (I): Células y órganos. AquaTIC. 2002. p. 16.

Flores Quintana, C. I. \& Portella, M. C. Histology and histochemistry of the digestive system development of Pseudoplatystoma fasciatum larvae. Abstracs World Aquaculture Society (Salvador, Bahia, Brasil). 2003a.

Flores Quintana, C. I. \& Portella, M. C. Histological analysis of juvenile Pseudoplatystoma fasciatum digestive system. Abstracs World Aquaculture Society (Salvador, Bahia, Brasil). 2003b.

Grau, A.; Crespo, S.; Sarasquete, M. C. \& Gonzales de Canales; M. L. The digestive tract of the amberjack Seriola dumerili Risso: A light and scanning electron microscope study. J. Fish Biol., 41:287-303, 1992.

Khanna, S. S. \& Mehrotra, B. K. Morphology and histology of the teleostean intestine. Anat. Anz. Bd.,129:1-18, 1971.

Moitra, S. K. \& Ray, A. K. The comparative morphohistology and anatomy of the digestive system of two indian freshwater perches, Ambassis nama (Ham.) and Ambassis ranga (Ham.) in relation to their food and feeding habits. Zool. Jb. Anat., 102:142-69, 1979.

Pereyra, L. A.; Domitrovic, H. A. \& Sampietro, J. C. Microscopía electrónica de barrido del tubo digestivo del surubí(Pseudoplatystoma coruscans y P. fasciaium) (Pisces, Siluriformes). Actas Reunión de Comunicaciones Científicas y Tecnológicas-UNNE. 1999: 10, 1-4.

Petrinec, Z.; Nejedli, S.; Kuz`ir S. \& Opac`ak, A. Mucosubstances of the digestive tract mucosa in northern pike (Esox lucius L.) and european catfish (Silurus glanis L.) Veterinarski Arhiv., 75:317-27, 2005.

Pignalberi, C.; Cordiviola de Yuan, E. \& Occhi, R. Anatomía e histología del aparato digestivo de Pimelodus albicans (Valenciennes) (Pises, Pimelodidae). Phycis Secc. B. Buenos Aires, 32:297-308, 1973.

Rossi, F. \& Luchini, L. Tecnologías para cultivo del "randia” (Rhamdia quelen) para fomento de su producción co- mercial, en clima templado a templado-cálido. Monografía. Sitio Argentino de Producción Animal. 2005, 20 pp.

http://www.produccionbovina.com/produccion_peces/00piscicultura.htm

Rotta, M. A. Aspectos gerais da fisiologia e estrutura do sistema digestivo dos peixes relacionados à piscicultura. Documentos / Embrapa Pantanal ISSN, 53:1517-973, 2003.

Sis, R. F.; Ives, P. J.; Jones, D. M.; Lewis, D. H. \& Haensly, W. E.. The microscopic anatomy of the oessophagus, stomach and intestine of the channel catfish, Ictalurus punctatus. J. Fish Biol., 14:179-86, 1979.

Teixeira de Seixas Filho, J.; de Moura Brás, J.; Tassis de Mendonça Gomide, A.; Goreti de Almeida Oliveira, M.; Lopes Donzele, J. \& Menin, E. Anatomia funcional e morfometria do intestino no Teleostei (Pisces) de água doce Surubim (Pseudoplatystoma coruscans - Agassiz, 1829). Rev. Bras. Zootec., 30:1670-80, 2001.

Correspondence to:

Dr. D. R. Hernández

Instituto de Ictiología del Nordeste

Facultad de Ciencias Veterinarias

Universidad Nacional del Nordeste (UNNE)

Sargento Cabral 2139

Corrientes

ARGENTINA

Tel.: +5403783425753 (171)

Email: dhernandez@vet.unne.edu.ar

Received: 28-09-2008

Accepted: 31-10-2008 
